\title{
Exploring Psalm 139 through the Jungian lenses of sensing, intuition, feeling and thinking
}

\begin{tabular}{|c|c|}
\hline $\begin{array}{l}\text { Authors: } \\
\text { Leslie J. Franc } \\
\text { Greg Smith } \\
\text { Alec S. Corio }\end{array}$ & $\mathrm{s}^{1,3}$ \\
\hline $\begin{array}{l}\text { Affiliations: } \\
{ }^{1} \text { Warwick Reli } \\
\text { Education Res } \\
\text { University of } \\
\text { United Kingd }\end{array}$ & $\begin{array}{l}\text { sions and } \\
\text { earch Unit, } \\
\text { Narwick, } \\
\text { m }\end{array}$ \\
\hline $\begin{array}{l}{ }^{2} \text { St George's } \\
\text { Stockport, wi } \\
\text { Adswood, Un }\end{array}$ & $\begin{array}{l}\text { hurch, } \\
\text { h St Gabriel, } \\
\text { ted Kingdom }\end{array}$ \\
\hline $\begin{array}{l}{ }^{3} \text { Department } \\
\text { Studies, Facul } \\
\text { and Religion, } \\
\text { Pretoria, Sout }\end{array}$ & $\begin{array}{l}\text { New Testament } \\
\text { y of Theology } \\
\text { Jniversity of } \\
\text { Africa }\end{array}$ \\
\hline $\begin{array}{l}\text { Research Proj } \\
\text { Project Leade } \\
\text { Aarde (D } \\
\text { Project Numb }\end{array}$ & $\begin{array}{l}\text { ect Registration: } \\
\text { r: A.G. van } \\
\text { er: } 2334682\end{array}$ \\
\hline $\begin{array}{l}\text { Description: } \\
\text { This research } \\
\text { research proj } \\
\text { Theology and } \\
\text { directed by Pr } \\
\text { van Aarde, Po } \\
\text { Professor and } \\
\text { Research Fell } \\
\text { Dean's Office, } \\
\text { Theology and } \\
\text { University of }\end{array}$ & $\begin{array}{l}\text { s part of the } \\
\text { ct, 'Biblical } \\
\text { Hermeneutics', } \\
\text { of. Dr Andries } \\
\text { st Retirement } \\
\text { Senior } \\
\text { w in the } \\
\text { Faculty of } \\
\text { Religion, } \\
\text { retoria. }\end{array}$ \\
\hline $\begin{array}{l}\text { Correspondin } \\
\text { Leslie Francis, } \\
\text { leslie.francis@ }\end{array}$ & $\begin{array}{l}\text { g author: } \\
\text { warwick.ac.uk }\end{array}$ \\
\hline $\begin{array}{l}\text { Dates: } \\
\text { Received: } 10 \\
\text { Accepted: } 05 \\
\text { Published: } 29\end{array}$ & $\begin{array}{l}\text { May } 2018 \\
\text { uly } 2018 \\
\text { Aug. } 2018\end{array}$ \\
\hline $\begin{array}{l}\text { How to cite th } \\
\text { Francis, L.J., S } \\
\text { Corio, A.S., } 20 \\
\text { Psalm } 139 \text { thr } \\
\text { Jungian lense } \\
\text { intuition, feel } \\
\text { thinking', HTS } \\
\text { Studies/Theol } \\
74(1), 5058 . h \\
\text { org/10.4102/ }\end{array}$ & $\begin{array}{l}\text { is article: } \\
\text { nith, G. \& } \\
\text { 18, 'Exploring } \\
\text { ough the } \\
\text { of sensing, } \\
\text { ng and } \\
\text { Teologiese } \\
\text { gical Studies } \\
\text { ttps://doi. } \\
\text { ts.v74i1.5058 }\end{array}$ \\
\hline Read online: & \\
\hline 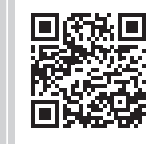 & $\begin{array}{l}\text { Scan this QR } \\
\text { code with your } \\
\text { smart phone or } \\
\text { mobile device } \\
\text { to read online. }\end{array}$ \\
\hline
\end{tabular}

Psalm 139 provides both great opportunities and huge challenges for the preacher. It is a Psalm crafted in four parts: part two is an imaginative and poetic affirmation of God's omnipresence that engages the Jungian perceiving process; part four is a fierce and uncompromising diatribe against God's enemies that engages the Jungian judging process. Interpretations of these two sections of the Psalm are explored among a sample of 30 Anglican deacons and priests serving as curates who were invited to work in small hermeneutical communities, structured according to psychological type theory and designed to test the sensing, intuition, feeling and thinking (SIFT) approach to biblical hermeneutics and liturgical preaching. The findings from the hermeneutical communities demonstrated that the poetic power of part two was perceived quite differently by sensing types and by intuitive types. The judgement against God's enemies in part four was evaluated quite differently by feeling types and by thinking types. The implications of these different readings of sacred text are discussed in relation both to hermeneutical theory and to homiletic practice.

\section{Introduction}

Psalm 139 provides both great opportunities and huge challenges for the preacher. It is a Psalm crafted in four parts (verses 1-6,7-12,13-18 and 19-24), with the second and fourth parts attracting particular critical attention among biblical commentators (see, e.g., Briggs 1909:491-502; Eaton 1967:301-303; Kirkpatrick 1903:786-792; Weiser 1962:799-808). Westermann (1981:256) identifies its uniqueness among the Psalms. Part two is an imaginative and poetic affirmation of God's omnipresence:

Where can I go from your spirit?

Or where can I flee from your presence? (Ps 139:7)

Part four begins with a fierce and uncompromising expression of invective and a petition for the destruction of God's enemies:

Do I not hate those who hate you, O Lord?

And do I not loath those who rise up against you?

I hate them with a perfect hatred.

I count them my enemies. (Ps 139:21-22)

Considerable effort has been expended by preachers and commentators (see Broyles 1999: 483-488) to provide a coherent account of the psalm's apparent changing moods and differing tones.

The recognised opportunities and challenges of Psalm 139 provide important and interesting texts on which to test the hermeneutical theory proposed by the sensing, intuition, feeling and thinking (SIFT) approach to biblical interpretation and liturgical preaching (see Francis \& Village 2008). The SIFT approach belongs to the reader perspective tradition of biblical interpretation. However, while the reader perspective tradition was originally rooted within sociologically informed categories characterising the distinctive location of the reader - like feminist perspectives (see Schottroff \& Wacker 2012), liberation perspectives (see Botta \& Andiňach 2009) and Black perspectives (see Brown 2004) - the SIFT approach is rooted within psychologically informed categories, drawing on psychological type theory (Jung 1971). Psychological type theory draws attention to the distinctive voices of the two perceiving functions (sensing and intuition) and to the distinctive voices of the two judging functions (feeling and thinking). The SIFT approach to biblical hermeneutics maintains that individuals who prefer sensing (sensing types) and individuals who

Copyright: (C) 2018. The Authors. Licensee: AOSIS. This work is licensed under the Creative Commons Attribution License. 
prefer intuition (intuitive types) perceive biblical texts in different ways and that individuals who prefer feeling (feeling types) and individuals who prefer thinking (thinking types) evaluate biblical texts in different ways.

The perceiving functions (see Myers \& McCaulley 1985:12) are concerned with the way in which people receive and process information; this can be done through use of sensing or through use of intuition. Sensing types (S) tend to focus on specific details, rather than the overall picture. They are concerned with the actual, the real and the practical and tend to be down-to-earth and matter-of-fact. They may feel that particular details are more significant than general patterns. They are frequently fond of the traditional and conventional. In contrast, intuitive types $(\mathrm{N})$ focus on the possibilities of a situation, perceiving meanings and relationships. They may feel that perception by the senses is not as valuable as information gained from the unconscious mind; indirect associations and concepts impact their perceptions. They focus on the overall picture, rather than specific facts and data. According to this theory, it would be hypothesised that sensing types and intuitive types would perceive the imaginative and poetic affirmation of God's omnipresence in part two of Psalm 139 in different ways.

The judging functions (see Myers \& McCaulley 1985:12-13) are concerned with the way in which people make decisions and judgements; this can be done through use of objective, impersonal logic or subjective interpersonal values. Thinking types $(\mathrm{T})$ make judgements based on objective, impersonal logic. They value integrity and justice. They are known for their truthfulness and for their desire for fairness. They consider conforming to principles to be of more importance than cultivating harmony. They are often good at making difficult decisions as they are able to analyse problems in order to reach an unbiased and reasonable solution. In contrast, feeling types (F) make judgements based on subjective, personal values. They value compassion and mercy. They are known for their tactfulness and for their desire for peace. They are more concerned to promote harmony than to adhere to abstract principles. They are able to take into account other people's feelings and values in decision-making and problem-solving, trying to reach a solution that satisfies everyone. According to this theory, it would be hypothesised that feeling types and thinking types would evaluate the fierce and uncompromising diatribe against God's enemies in part four of Psalm 139 in different ways.

The SIFT approach to biblical hermeneutics and liturgical preaching was initially developed on the basis of theoretical extrapolation from psychological type theory and tested by a rigorous application of that theory to the principal Gospel readings proposed by the Revised Common Lectionary by Francis and Atkins (2000; 2001; 2002). More recently, the SIFT approach has been tested by a series of empirical studies. Each study in the series has selected a passage of scripture and invited participants to explore and to respond to that passage of scripture working in groups that have drawn together individuals of similar psychological type preferences.

The following passages of scripture have been explored in these empirical studies: the feeding of the five thousand reported in Mark 6:34-44 (Francis 2010); the resurrection narratives reported in Mark 16:1-8 and Matthew 28:1-15 (Francis \& Jones 2011); the cleansing of the Temple and the incident of the fig tree reported in Mark 11:11-21 (Francis 2012a; Francis \& ap Siôn 2016a); the Johannine feeding narrative reported in John 6:4-22 (Francis 2012b); the narrative of separating sheep from goats reported in Matthew 25:31-46 (Francis \& Smith 2012); the birth narratives reported in Matthew 2:13-20 and Luke 2:8-16 (Francis \& Smith 2013); two narratives concerning John the Baptist reported in Mark 1:2-8 and Luke 3:2b-20 (Francis 2013; Francis \& Smith 2014); the Johannine feeding narrative reported in John 6:5-15 (Francis \& Jones 2014); two passages from Mark exploring different aspects of discipleship reported in Mark 6:7-14 and Mark 6:33-41 (Francis \& Jones 2015a); the foot washing account reported in John 13:2b-15 (Francis 2015); two healing narratives reported in Mark 2:1-12 and Mark 10:46-52 (Francis \& Jones 2015b); the narrative of blind Bartimaeus reported in Mark 10:46-52 (Smith \& Francis 2016), the Road to Emmaus narrative in Luke 24:13-35 (Francis \& ap Siôn 2016b; Francis \& Smith 2017); the Lucan call of the first disciples reported in Luke 5:1-7 (Francis \& ap Siôn 2017); and the missionary journey reported in Mark 6:6b-16 (Francis, Smith \& Francis-Dehquani 2017). More recently, this research tradition has also been applied in Poland by Chaim (2013, 2014, 2015).

\section{Research question}

Building on this established empirical research tradition, the aim of the present study was to invite a number of Anglican clergy to work in type-alike groups to explore their reading of part two and part four of Psalm 139. The type-alike groups were structured on the basis of the perceiving process (distinguishing between sensing types and intuitive types) to explore part two (vv. 7-12) that is rich in material to engage the perceiving process and on the basis of the judging process (distinguishing between feeling types and thinking types) to explore part four (vv. 19-24) that is rich in material to engage the judging process.

\section{Method Procedure}

The context was a one-day programme (including practical workshops), arranged for deacons and priests serving as curates within a Church of England Diocese, on the topic of 'Reading the Bible with different types'. The scene was set by exploring the theology of individual differences and by reminding the participants of their earlier introduction to psychological type theory. The majority of the 30 participants were type aware, but sufficient introduction to the theory was provided to refresh this awareness. The participants were first invited to work in three groups according to their 
preferences on the perceiving process: these groups divided into 11 sensing types, 10 strong intuitive types and 9 less strong intuitive types. Then the participants were invited to work in three groups according to their preference on the judging process: these groups comprised 7 thinking types, 13 strong feeling types and 10 less strong feeling types. Participants were relied upon to recall their scores accurately from a previous workshop and arrange themselves accordingly.

\section{Materials}

The participants in the groups arranged according to the perceiving process were given a printed copy of Psalm 139:712, from the New Revised Standard Version (Anglicised Edition), with the following instructions: 'Please focus attention on these verses only, rather than on the whole Psalm. What do you see in this passage and what sparks your imagination?' (see Appendix 1)

The participants in the groups arranged according to the judging process were given a printed copy of Psalm 139:1924, also from the New Revised Standard Version (Anglicised Edition), with the following instruction: 'Please focus attention on these verses only, rather than on the whole Psalm. What issues in this passage touch your heart and stretch your mind?' (see Appendix 2)

All groups were asked to appoint one participant to take notes of the discussion and to report back to the plenary session so that the insights of each group could be shared with those in other groups.

\section{Analysis}

One of the three authors served as an observer in each group and noted the discussion carefully. The following analysis documents the discussion.

\section{Results: Psalm 139:7-11 \\ Sensing group}

The group of self-identified sensing types numbered 11 . They commenced the exercise in complete silence, reading the passage very intently. Members of the group spoke in an orderly fashion, never interrupting each other, although there were occasions when they gently challenged or contradicted each other. On two separate occasions, the first with still 15 minutes to go, it appeared that they had run out of things to say and there were extended periods of silence. The exercise finished when one of the group very punctually arose without ceremony to lead the remainder back into the plenary session: here, they agreed that they had been given more than sufficient time for the exercise.

The first voice spoke of being in touch with the world around her, and yet at the same time being lifted out of it by the Psalm. A second voice affirmed the bubble of protection that the Psalm provided. Another voice was reassured by the boundaries that the Psalm provided, while another disputed this - surely there were no boundaries. There were further attempts to interpret the verses quite literally, declining to view the opening question as being rhetorical, rather genuine and 'desperate' pleas for escape.

There was repeated use of language often associated with sensing types. Different voices spoke of being 'earthed', the 'grounded way of introducing possibilities' and 'logical arguments - if this, then that', while another voice noted that this was a 'growing (i.e. evolving) description of God'. The group was careful to weigh individual words and press their definition: darkness might refer to sin, or to the opposite of God, or simply denote being in a dark place. Similarly, one voice enquired whether Sheol was a place you could imagine God to be. What was the right word, the group wondered, to describe what was being depicted in the Psalm? If we speak of 'safety', are we referring to the here and now or to the ultimate? Neither 'safe' nor 'held' quite fitted, but possibly 'assured' was the right term.

Further literalist interpretations were provided when one voice who had been asked whether he was reading the passage with his head or heart, responded that imaginative thoughts came from his head.

Some members of the group displayed anxiety about whether they were engaging with the task in the right way. Perhaps we are shallow, one voice feared, while another sought reassurance from the observer that they were doing it right.

Eventually, one voice wanted to explore what others would focus on if they were preaching on the passage; before receiving his answer, he opined that in his case it would be the refrain: You are there. The suggested use of a refrain, a familiar phrase, much appealed to this group of sensing types.

The group's discussion concluded with consideration of the 'right hand' referred to in the text. Different voices identified a variety of practical implications. One contributor, a father with a young daughter, described an incident in which he had encountered a fallen tree and had led his daughter by hand to view it more closely, recognising the implicit trust that this entailed. Another voice contrasted leading with holding. A third voice noticed that, if we are held by God's right hand, this necessarily means that God places us on his right side. We ended with one very practical reflection. A left-handed person enquired whether it was acceptable to give a blessing with his left hand, or was the right hand always necessary for this? There was no time to answer. At no juncture had the group succumbed to the temptation to explore the rest of the Psalm, resolutely maintaining the discipline of the task before them.

\section{Intuitive group one}

The group of 10 strong intuitive types read the passage aloud and thought for a moment before an extravert participant 
spoke out, 'It is simple. The big idea is that God is everywhere! There is no more to be said.'

This big idea, however, quickly sparked others to expand on the succinct summary: the Psalm is saying something really important about God. God is there all the time, omnipotent, in all circumstances, and at all times, even when you cannot see him. God is present in the good and bad times of life, in the light and in the darkness.

This big idea has a negative side to it as well. It is an oppressive view of God. God sees it all and you cannot escape from God however much you want to do so. This perspective reminded one voice in the group that she used this Psalm to oppress her atheist brother-in-law. I tell him that he cannot hide from God. God sees our sins, knows our thoughts, whether we believe in God or not.

Another voice used the Psalm in a gentle way to engage dialogue with atheists. She took the view that the Psalm was really affirming for everyone. She argued that it doesn't matter whether you believe in God or not. You are being held by God, God is always holding your hand whether you know it or not. She argued that this Psalm is written for everyone, not just those who know the Lord.

This big idea of inclusivity offended another member of the group who rejected the view as soft universalism. His preference was to tell the atheist openly: you are wrong, God sees it all and you don't have a hope in hell.

Given that the first big idea seemed to be leading into conflict, another member of the group introduced a new line of explanation. For her, the big idea was to do with religious language. For her, the Psalm was extremely poetic, a poetic truth statement. What is being said here is all too much. You cannot take it literally, but there is a truth to it. You get it, even if you haven't got a faith.

This big idea led to an examination of some of the poetic imagery within the Psalm. The idea that darkness is as light to you is just beautiful. It spoke to one member of the group at a point of depression in her life: 'I want to say that God is with us in our darkness because of my own experience. God was there in the darkest part of my life.'

The image of darkness sparked another thought. This image is profound because it affirms that God actually sees in the darkness. God does not switch on the lights, God actually sees in the darkness. God is not limited by darkness.

Another powerful image is that of 'the wings of the morning'. This image sparked recollection of magical experiences of the early morning, the clear light, the clarity of vision, the experience of growing up in the tropics when the morning light came in quickly and so decisively.

Other powerful images that sparked conversation included the notion of ascending into heaven (stretching out for the highest aspiration) and making my bed in Sheol (making my bed and sleeping on it, shaping bad choices). Poetry cannot be taken too literally. It must always open the mind and spark new connections. There is something very incarnational in poetry. There is theology in a big way here.

At this point, there was a new direction taken as another voice wanted to explore how the poetry and theology of the Psalm could be employed in the Church. What does the poetry mean when you hear it in church on Sunday, or when you go to work or to school on Monday?

This big idea sparked a conversation about the positive ways in which the Psalm could be used in the Christian life. One voice used it at funerals and for the interment of ashes. It is a Psalm that brings hope in darkness. Another member of the group remembered that she had read this at her grandfather's funeral, an occasion when most of the participants were not churchgoers. It seemed to speak to them too.

By now the 30 minutes allocated for the workshop had just disappeared. The participant who had been the first to speak and who had considered at that point that there was nothing more to say had been busily engaged throughout and was now reluctant to see the conversation drawn to a close. There was still so much to discover.

\section{Intuitive group two}

After arranging themselves into a group, there was a short period of quiet. Then the group of nine less strong intuitive types awkwardly discussed who would take notes for feedback. After a failed attempt to nominate a somewhat reluctant member of the group for this task, one of the participants put himself forward and volunteered to take notes and deliver feedback.

After another short period of quiet, and at the suggestion of one participant, two participants read the passage aloud. Quite quickly after hearing the passage read aloud this group of intuitive types began to discuss the imagery of the passage. Initially, the metaphors centring on space, movement and light were pointed out. Then the contrasts between light and dark, heaven and hell were noticed. Participants questioned how much the passage can be read as words of comfort and peace, and whether it shows the universality of God's love. There was then a brief discussion of the author or authors of the Psalm, where they might be coming from or what experience they had gone through. One voice asked whether the Psalmist was wondering what he could hold on to in the midst of darkness.

Then the image of the wings of the morning attracted the attention of the group. One voice said this spoke to him of the author's ambiguous backstory: that it might reflect being distracted and lost far from home. Another participant observed that these could either be words of challenge or comfort, depending on the reader's position. Another imagined the image as a tattoo. A fourth participant said she 
would just like to let her imagination run with the image of leading, holding and brightness. Then one member of the group of intuitive types invited the others to reflect on how they would draw on these rich images in prayer and preaching. Some participants said that much of their preaching was about how the lections make them feel and that their imagery was an important aspect of this. Other associations of the passage sprang to mind. One voice commented that it reminded her of music - and in particular Mendelssohn's 'O for the wings of a dove'. Attention then turned to the imagery of the sea, sparking a variety of associations: the sea as a source of chaos, the sea as a place beyond our mental horizons, or the sea as a place of eschatological hope linked to Revelation Chapter 21.

Next, this group of intuitive types explored the potential pastoral uses of the passage. One participant thought it might be a helpful passage to speak of mental illness, particularly bipolar disorder or depression. Another participant noted the mention of God's right hand and the image of God's strong right hand holding our weaker left hand. Two participants noted that they already used the passage in the context of compline and morning prayer, where it is stilling and helps them to remain confident in God's direction wherever their day goes. Other participants said it spoke to them of healing, of depression and disability. Another participant wondered whether it might be helpful in supporting refugees and asylum seekers, particularly an individual in his parish under threat of deportation.

The mention of refugees and asylum seekers inspired another voice to link the imagery with the lonely and isolated world of the Internet. He talked of using the passage with young men tempted towards inappropriate use of the Internet, where sin thrives because no one is watching. Another participant linked the solitary world of the Internet with the isolation experienced by clergy. He observed that, for clergy working alone much of the time, the passage also seemed appropriate as reminding them that their time is accountable. Returning to the theme of its use at compline, another participant imagined it being sewn into a quilt enveloping us through the hours of darkness.

\section{Results: Psalm 139:19-24 Feeling group one}

The group of 13 self-identified high-scoring feeling types commenced the task when one of their members volunteered to read the passage aloud. Having done so, she reflected on how had she been reading the passage in church, she would have read it more 'pleadingly'. Encouraged by the group, she proceeded to read the passage a second time, attempting to inject a pleading tone to her delivery.

A second voice immediately focused on the controversial use of the word 'hatred' in the psalm. 'I don't hate' but questions were raised about what is going on in the world, especially where there were strong feelings against Christians. A third participant identified the judgemental tone of the Psalmist, but wondered whether the writer knew that there was something in him. Thereupon, the first voice explained that this was the reason for switching from an angry note to a more pleading one. This endorsement assisted the third voice to equate 'perfect hatred' with righteous anger.

A fourth participant noted how the psalm displays the full range of human emotions. This contributor opined: 'it makes me deeply uncomfortable', recognising that it was not necessarily helpful that this section of the psalm was often omitted by some parts of the Anglican Church. This observation prompted further thoughts about the liturgical role of the psalm. A new contributor confessed to finding that saying this psalm is difficult at Morning and Evening Prayer, precisely because it did not coincide the contributor's own feelings. The solution, this contributor suggested was to employ the psalm as an opportunity to pray: first for those who felt rage and anger, and then for those who felt emptied and vulnerable.

The group continued to attempt to ameliorate the negative feelings and discomfort engendered by grappling with the passage. The second voice took comfort from the notion that God knows the 'dark parts' inside us. The original reader considered that we need to look outside the passage to make it better. A new voice stated that this (hatred and anger) was a reality for some people in the world. The participant whose concern had been for the liturgy now wondered whether, despite its being in the Bible, it was right? And whether it could be said by someone who didn't agree with it? These were genuine rather than rhetorical questions. The third voice wanted to read the passage through the Christian lens of loving your enemies. The fourth voice, who had previously expressed profound discomfort, suggested that the overriding thrust of Scripture was a love story. Meanwhile, a new voice was prompted to remark how passion for the love of God was being expressed in words that this group found difficult.

The third voice now declared that reading the passage as a new Christian might read it could assist understanding of the passion exhibited in the passage. The participant who had remarked on passion noted 'I used to feel I need to defend God' because 'I wanted everyone to feel like I did'. A voice that had previously not contributed suggested it was possible to imagine a situation in which it was so intolerable, and the effect on the victim so awful, that it became possible to say: I wish you were dead! Yes, the passionate voice affirmed: lashing out, but in a passionate, loving way. Perhaps, another voice wondered, the Psalmist was a victim?

The liturgical voice was the first to root the conversation in the real world, imagining how these words might be addressed to God with a terrorist group in mind, with the emphasis on 'You', that is, God killing the wicked, in other words saying: It's in Your hands, O God. Another voice wanted to read the psalm as a lament, recognising how contemporary worship songs omit this dimension. The third voice continued to muse on how the psalm could be read differently dependent on individual circumstances. The first 
voice spoke of how the passage presented an opportunity to 'check out my heart', inviting questions such as who am I, and am I any different from them? Recognising this danger, the third voice referenced clergy who used their position for evil and those who used Christianity as an opportunity to speak evil. The real-world voice opined that it was helpful to discuss this as a group, having found it difficult to watch the news 'because of Trump', but now understanding how this passage held up a mirror. The third voice reminded the group that, if the passage was omitted from our liturgy, we deny the congregation the opportunity to make sense of it.

The final word was left to the individual who proclaimed that it made Jesus' teaching more radical. On all occasions, participants spoke gently, avoiding conflict and offering their viewpoint as being complementary to what had gone before.

\section{Feeling group two}

After a brief period of quiet, one participant in the group of 10 less strong feeling types asked whether anyone had any thoughts they would like to share with the group. Lack of comfort with the passage became quickly apparent. Several participants replied that their first thought was that they did not want to preach on this passage. One participant commented that whenever Psalm 139 appears in the lectionary, he hopes it ends before 'the difficult bit'. Then the group discussed possible ways of reading the section, particularly focusing on whether the tone of the psalm changes in v. 23. One voice noted that this is a stark contrast. Another participant wondered whether the author has been struck by the understanding that what he has been saying is wrong and self-righteous. A third participant wondered whether it was a plea of redemption, so that the author might not be swept away as the wicked.

The group of feeling types then spent some time discussing the word 'hate' and questioning how hatred can be perfect. One participant said that 'hate' is a 'hard word'. Another participant wondered whether it was being used hyperbolically, to mean something like 'reject' or 'set aside'. A third participant asked whether hatred has a place in God's love; whether God's hatred is for those who damage God's creation.

One participant asked why we tend not to use imprecatory psalms in worship. A church historian in the group gave a little historical context about the revision of the liturgical Psalter in 1917, when convocation voted to omit such passages. Randall Davison spoke about the Church wishing to be a voice for peace, and the reason for editing the Psalter in this way; the next day the news was filled with headlines expressing anger against the Germans that were just as hard as the language of the Psalms.

Another participant then observed that we often need a godly way of expressing anger, and talked about using imprecatory Psalms with gang members in his parish, who can verbally rather than physically express their anger through this language. There was then a bit of reflection on the connection between the crucifixion of Christ, Christian pacifism, and how a wrathful image of God fits in. One participant commented that human violence, in contrast, always has negative consequences for people - both on victims and perpetrators.

This group of feeling types then returned to the word 'hatred', and there was much questioning about how that word can be understood in the Christian context. One voice wondered whether perfect hatred is a hatred that serves love. Another participant asked whether it is a hatred of evil alone. A third participant asked whether it is the hatred of the enemies of the Lord. A fourth participant spoke of capital punishment and asked whether the punishment itself is hatred or the consequences of hatred. They questioned whether the Psalmist is talking about the consequences of hating God. A fifth voice noticed the number of times the psalm mentioned God's enemies, rather than the enemies of the author, and wondered whether the author is able to recognise that God will deal with them, and for him to kill them would be wrong.

A participant noted that we find it hard to reconcile hatred with the cross and its love and forgiveness, but that there is language in the New Testament that shows God's judgement is harsh too. Another participant talked of the way of God being pure, but that violence carries a stain. A third voice wondered whether the psalm could be rephrased as a question to God, about why God does not destroy the wicked. Is it, perhaps, to give them an opportunity to repent?

Then this group of feeling types reflected on the danger of over-spiritualising their response to the psalm and oversanitising their feelings. One participant said that there could be a danger of not speaking out against evil and of not recognising the enemy, because we ourselves rarely experience what it is like to be the victim of injustice. This was echoed by other participants. One participant observed that, if we were persecuted Christians (e.g. in Mosul), the words of the psalm would speak to us more clearly. Another participant said that they could imagine feeling such anger when reading of leniency in sentencing or unfairness in a court case. This group of feeling types began to explore how far they could put themselves in the shoes of those who were driven to shout out in anger in the way in which the Psalmist was doing.

\section{Thinking group}

The group of seven thinking types was affronted by the passage. Quite quickly an adversarial approach was adopted in a form of arguments and counterarguments between one conservative voice who was wishing to defend the scriptural proclamation of the Psalmist and several liberal voices who found the dominant view of God portrayed in the psalm as offensive.

The first four voices to speak said: 'I am struggling to get beyond the third line'; 'These are very violent words, like 
hate'; 'I do not like the wrathful God of the Old Testament'; 'This is an affront to me'. Then the conservative voice countered such criticism of sacred text, saying that he found this a comforting passage. He argued that the passage gave assurance that those who are righteous before God will be supported by God. Those who love God will be rewarded and those who hate God will be destroyed. This is a lesson against those who rise up against God and who deny even the existence of God.

The wider group set out to challenge this interpretation. For them, the account was far too 'black and white'. 'I find this passage difficult', said one:

because I spend my life trying to persuade people to believe in God, but who would want to believe in a God like this. The passage plays straight into the hands of people like Richard Dawkins.

Another voice said that the idea that I should hate people is anathema to me. Our job as Christians is to love our enemies and to turn the other cheek. This point was amplified by someone who had indeed hated her enemies and who as a Christian had struggled to overcome hatred with forgiveness and acceptance. The Christian way is the way of forgiveness. The Christian God does not hate people. See how Jesus prayed forgiveness for those who were crucifying him: 'Father they know not what they do.'

The conservative voice came back into the conversation with insistent clarity, defending the right of God to pass judgement. 'Listen', said one of the liberal voices:

we are not challenging God's right to pass judgement. But who are we to pass judgement and to hate others with a perfect hatred as the Psalm proclaims. I really do not want to be that kind of person.

In an attempt to clarify the grounds for disagreement between the two perspectives, some members of the group turned their attention back to the words of the passage and proposed an alternative reading. According to this alternative reading, the first eight lines represented the Psalmist's great cry of pain and frustration. Here, the Psalmist was crying out to God for vindication 'Oh that you would kill the wicked, O God'. The world would be a better place without the wicked and God could clean it up so quickly. I hate them and God should kill them. Then, in the last four verses, the Psalmist begins to appreciate the enormity of what he is asking. Is he really as rock solid as he imagines? Perhaps if God looked too closely at his life, he too might fall under judgement. The final verse could be a prayer of contrition, following the outburst of hatred, a prayer to 'lead me in a way everlasting'. Here is an external processor who has to get all these angry thoughts out of his system before he can progress to repentance and restoration.

Seizing on this alternative reading of the psalm, another member of the group stressed that it was right to feel uncomfortable with the language of hatred. Yet it was important to recognise that here it was the Psalmist speaking, not God speaking. The Psalmist could scream out for God to destroy the wicked, but God was not obliged to act as the Psalmist asked.

The conservative voice was still not convinced. He fully believed in the holiness of God and God's right to measure out justice on the wicked. Then, this position was challenged. So, does that mean that we should take up arms to fight God's battles for God? Would it be right to send in the British army to wipe out a nation, enacting God's judgement on them, in fulfilment of the Psalmist's claim, 'I hate them with perfect hatred; I count them my enemies'? How would you square that with Jesus' command to love your enemies?

The allocated time had passed quickly and the argument could have gone on much longer, without agreement appearing over the horizon.

\section{Conclusion}

The groups organised according to their perceiving functions (sensing or intuition) demonstrate how different types explore poetry to be found in Scripture, the Psalms being a rich source of this. Sensing types seek to press words and phrases, wringing out every inference and practical application. Intuitive types, by contrast, are excited by the 'big ideas' to which the psalm points. They are quick to recognise allusions to other scriptural references and to other Christian ideas. Intuitive types, it seems, are energised by the exposure a group process like this brings to other people's ideas, which in turn spark further ideas of their own. Sensing types are much more concerned with the practical application of engaging with Scripture: how will they preach? What help will the insights bring to troubled parishioners?

The exercise suggests that intuitive types and sensing types need each other. Sensing types need their intuitive colleagues to remind them that the exploration of Scripture is exciting and life-giving; that there is no end to the inspiration a passage may provide, no finite amount of learning to be gleaned. Meanwhile, intuitive types need to be reminded that ethereal ideas ultimately need to be grounded in the practicalities of living in the world around us with its myriad challenges.

The groups organised according to their judging functions (thinking and feeling) all wrestled with the imprecations delivered in the final section of Psalm 139, but they dealt with their struggle in characteristically different ways. The feeling types tended to feel uncomfortable when confronted by this Psalm and would have preferred to leave the last section unread. The Psalm was damaging to their worldview of peace and harmony and threatened their image of the God of mercy. The thinking types were affronted by the passage, and they found the passage difficult; but they could not ignore it. They needed to struggle with the tensions and with the contradictions. They needed to offer a coherent synthesis between the God of justice and the God of mercy. 
The exercise suggests that feeling types and thinking types need each other. Feeling types need their thinking colleagues to remind them that it is simply not good enough to ignore those passages of Scripture that leave the reader feeling uncomfortable. When feeling types fail to address problematic texts of this nature from the pulpit, thinking types within the congregation may feel let down or betrayed. Meanwhile, thinking types need their feeling colleagues to remind them how costly some people may find dealing with passages of Scripture that involve the wrath of God. When thinking types confront the toughness of such texts from the pulpit, feeling types within the congregation may go away feeling bruised.

Finally, the real benefit of this one-day programme and workshops was realised in the plenary session when the three groups who had been working separately came together to show the content and process of each group. The revelation occurs when sensing types and intuitive types hear the clear differences between their distinctive perceptions and when feeling types and thinking types hear the clear differences between their distinctive evaluations. The psychological type preferences of the reader have a clear part to play in the hermeneutical process of biblical interpretation.

\section{Acknowledgements \\ Competing interests}

The authors declare that they have no financial or personal relationships which may have inappropriately influenced them in writing this article.

\section{Authors' contribution}

This research project was conceptualised and led by L.J.F. G.S. and A.S.C. took a full part in the collection and interpretation of the data and contributed to the writing of the article.

\section{References}

Botta, A.F. \& Andiňach, P.R. (eds.), 2009, The Bible and the hermeneutics of liberation, Brill, Leiden.

Briggs, C.A., 1909, A critical and exegetical commentary on the Book of Psalms, vol. 2, T and T Clark, Edinburgh.

Brown, M.J., 2004, Blackening of the Bible: The aims of African American biblical scholarship, Continuum, London.

Broyles, C.C., 1999, New International Biblical Commentary: Psalms, Hendrickson Publishers, Peabody, MA.

Chaim, W., 2013, 'Typy psychologiczne w recepcji i przekazie slowa bożego' [Psychological typology in the reception and transmission of the Word of God], Roczniki Pastoralno-Katechetyczne 5, 155-170.

Chaim, W., 2014, 'Metoda interpretacji i przepowiadania slowa bożego SIFT w slużbie kaznodziejstwa cala dusza' [The SIFT method in the service of preaching with all our souls], Roczniki Teologiczne 61, 117-136.

Chaim, W., 2015, 'Profil typu psychologicznego, interpretacja biblii I głoszenie słowa bożego (badania empiryczne)' [Psychological type profile, biblical hermeneutics and liturgical preaching (empirical research)], Resovia Sacra 22, 45-69.

Eaton, J.H., 1967, Psalms: Introduction and commentary, SCM, London.
Francis, L.J., 2010, 'Five loaves and two fishes: An empirical study in psychological type and biblical hermeneutics among Anglican preachers', HTS Theological Studies 66(1) art. \#811, 1-5. https://doi.org/10.4102/hts.v66i1.811

Francis, L.J., 2012a, 'What happened to the fig tree? An empirical study in psychological type and biblical hermeneutics', Mental Health, Religion and Culture 15, 873-891. https://doi.org/10.1080/13674676.2012.676252

Francis, L.J., 2012b, 'Interpreting and responding to the Johannine feeding narrative: An empirical study in the SIFT hermeneutical method among Anglican ministry training candidates', HTS Theological Studies 68(1) art. \#1205, 1-9.

Francis, L.J., 2013, 'Ordinary readers and reader perspective on sacred texts: Drawing on empirical theology and Jungian psychology', in J. Astley \& L.J. Francis (eds.), Exploring ordinary theology: Dimensions of everyday Christian existence and the life of the Church, pp. 87-96, Ashgate, Farnham.

Francis, L.J., 2015, 'Footwashing and diaconal ordination', in J. Vincent (ed.), The farewell discourses in practice, pp. 21-28, Deo Publishing, Blandford Forum.

Francis, L.J. \& ap Siôn, T., 2016a, 'Jesus, psychological type and conflict: A study in biblical hermeneutics applying the reader perspective and SIFT approach to Mark 11:11-21', HTS Theological Studies 72(4), 1-9. https://doi.org/10.4102/hts. v72i 4.3573

Francis, L.J. \& ap Siôn, T., 2016b, 'Empirical theology and biblical hermeneutics: Exploring lessons for discipleship from the Road to Emmaus (Luke 24:13-35)',
Journal of Empirical Theology 29, 24-44. https://doi.org/10.1163/1570925612341000

Francis, L.J. \& ap Siôn, T., 2017, 'Reading the Lucan call of the first disciples differently: The voices of sensing and intuition', Journal of Beliefs and Values 38, 188-198. https://doi.org/10.1080/13617672.2017.1291254

Francis, L.J. \& Atkins, P., 2000, Exploring Luke's Gospel: A guide to the gospel readings in the Revised Common Lectionary, Mowbray, London.

Francis, L.J. \& Atkins, P., 2001, Exploring Matthew's Gospel: A guide to the gospe readings in the Revised Common Lectionary, Mowbray, London.

Francis, L.J. \& Atkins, P., 2002, Exploring Mark's Gospel: An aid for readers and preachers using year $B$ of the Revised Common Lectionary, Continuum, London.

Francis, L.J. \& Jones, S.H., 2011, 'Reading and proclaiming the resurrection: An

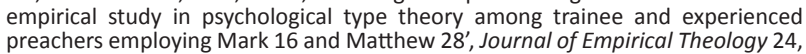
preachers employing Mark 16 and Matthew 28', Journe
$1-18$. https://doi.org/10.1163/157092511X571141

Francis, L.J. \& Jones, S.H., 2014, 'Life in the eucharistic community: An empirical study in psychological type theory and biblical hermeneutics reading John 6:5-15', in psychological type theory and biblical hermeneutics reading John 6:5-15,
Pastoral Psychology 63, 281-290. https://doi.org/10.1007/s11089-013-0540-x

Francis, L.J. \& Jones, S.H., 2015a, 'An empirical approach to Mark's account of discipleship: Conversation between the Word of God and the People of God', Rural Theology 13, 69-81. https://doi.org/10.1179/1470499415Z.00000000042

Francis, L.J. \& Jones, S.H., 2015b, 'Preparing for disability awareness Sunday: An educational exercise drawing on psychological perspectives for biblical hermeneutics', International Journal of Christianity and Education 19, 197-214. https://doi.org/10.1177/2056997115602485

Francis, L.J. \& Smith, G., 2012, 'Separating sheep from goats: Using psychological type theory in a preaching workshop on Matthew 25:31-46', Journal of Adult Theological Education 9, 175-191. https://doi.org/10.1179/ate.9.2.gw215220 35374468

Francis, L.J. \& Smith, G., 2013, 'Reading and proclaiming the birth narratives from Luke and Matthew: A study in empirical theology among curates and their training incumbents employing the SIFT method', HTS Theological Studies 69(1), article 2001, 1-13. https://doi.org/10.4102/hts.v69i1.2001

Francis, L.J. \& Smith, G., 2014, 'Reading and proclaiming the Advent call of John the Baptist: An empirical enquiry employing the SIFT method', HTS Theologica Studies 70(1), article 2718, 1-9. https://doi.org/10.4102/hts.v70i1.2718

Francis, L.J. \& Smith, G. 2017. 'Learning relationships: Church of England curates and training incumbents applying the SIFT approach to the Road to Emmaus', HTS Theological Studies 73(4), article 4546. https://doi.org/10.4102/hts.v73i4.4546

Francis, L.J., Smith, G. \& Francis-Dehqani, G., 2017, 'The missionary journey of Mark 6 and the experience of ministry in today's world: An empirical study in biblical hermeneutics among Anglican clergy', HTS Theological Studies 73(3), article 4560 https://doi.org/10.4102/hts.v73i3.4560

Francis, L.J. \& Village, A., 2008, Preaching with all our souls, Continuum, London.

Jung, C.G., 1971, Psychological types: The collected works, vol. 6, Routledge and Kegan Paul, London.

Kirkpatrick, A.F., 1903, The Book of Psalms, Cambridge University Press, Cambridge.

Myers, I.B. \& McCaulley, M.H., 1985, Manual: A guide to the development and use of the Myers-Briggs type indicator, Consulting Psychologists Press, Palo Alto, CA.

Schottroff, L. \& Wacker, M.-T. (eds.), 2012, Feminist biblical interpretation: A compendium of critical commentary on the Books of the Bible and related literature, Eerdmans, Grand Rapids, MI.

Smith, G. \& Francis, L.J., 2016, 'Difficult texts: Mark 10:46-52', Theology 119, 200-203. https://doi.org/10.1177/0040571X15623706

Weiser, A., 1962, The Psalms: A commentary, SCM Press, London.

Westermann, C., 1981, Praise and Lament in the Psalms, T \& T Clark, Edinburgh. 


\section{Appendix A}

\section{Psalm 139:7-12}

Where can I go from your spirit?

Or where can I flee from your presence?

If I ascend to heaven, you are there;

if I make my bed in Sheol, you are there.

If I take the wings of the morning and settle at the farthest limits of the sea, even there your hand shall lead me, and your right hand shall hold me fast.

If I say, 'Surely the darkness shall cover me, and the light around me become night', even the darkness is not dark to you; the night is as bright as the day, for darkness is as light to you.

Please focus attention on these verses only, rather than on the whole Psalm. What do you see in this passage and what sparks your imagination?

Source: New Revised Standard Version (Anglicised Edition)

\section{Appendix B}

\section{Psalm 139:19-24}

O that you would kill the wicked, O God, and that the bloodthirsty would depart from methose who speak of you maliciously, and lift themselves up against you for evil!

Do I not hate those who hate you, O Lord? And do I not loathe those who rise up against you?

I hate them with perfect hatred; I count them my enemies.

Search me, O God, and know my heart; test me and know my thoughts.

See if there is any wicked way in me, and lead me in the way everlasting.

Please focus attention on these verses only, rather than on the whole Psalm. What issues in this passage touch your heart and stretch your mind?

Source: New Revised Standard Version (Anglicised Edition) 